\title{
The Effect of Platelet-Rich Plasma In Vitro on Primary Cells: Rat Osteoblast-like Cells and Human Endothelial Cells
}

\author{
Robert E.C.M. Mooren, M.D., D.M.D., ${ }^{1, *}$ Eef J. Hendriks, Medical Student, ${ }^{2, *}$ \\ Jeroen J.J.P. van den Beucken, Ph.D., ${ }^{2}$ Mathijs A.W. Merkx, M.D., D.M.D., Ph.D., \\ Gert J. Meijer, D.M.D., Ph.D.,,2 John A. Jansen, D.M.D., Ph.D., ${ }^{2}$ \\ and Paul J.W. Stoelinga, M.D., D.M.D., Ph.D.1
}

The aim of this study was to evaluate the effects of standardized platelet-rich plasma (PRP) concentrates from 10 human donors on cellular behavior. The standardized PRPs used were fivefold average and fivefold maximum baseline values in whole blood. Both these standardized PRPs were characterized by determining platelet numbers and subsequently growth factor concentrations in activated PRPs, called PRP derivatives. Platelet numbers in both types of standardized PRPs were significantly increased compared with whole blood. Further, both PRP derivatives contained significantly higher concentrations of platelet-derived growth factor-AA, platelet-derived growth factor- $\mathrm{AB}$, and transforming growth factor-beta 1. Vascular endothelial growth factor concentrations were significantly elevated in only the most concentrated PRP derivative. Cell culture experiments with osteoblast-like cells showed that both PRP derivatives stimulated cell proliferation without inducing cell differentiation, whereas tube formation in endothelial cell cultures was significantly increased by adding low volume percentages of PRP derivative $(2 \%-8 \%)$. Consequently, it can be concluded that there is no direct relationship between the number of platelets and the level of growth factors released from these platelets. PRP derivatives have the potency to stimulate angiogenesis dose dependently, while lacking the capacity to induce osteogenic differentiation. Yet, the proliferation of osteoblast-like cells can significantly be enhanced by supplementation of PRP derivatives.

\section{Introduction}

G ROWTH FACTORS RELEASED by activated platelets are supposed to have a stimulating effect on several kinds of cells involved in initial bone (wound) healing, for example, osteoblasts, endothelial cells, fibroblasts, and mesenchymal stem cells. The basic hypothesis of adding plateletrich plasma (PRP) to bone grafts is that high concentrations of the released growth factors enhance the initial wound healing response. ${ }^{1-3}$

After the introduction of PRP as a strategy to enhance bone healing, several clinical and experimental studies have been carried out. Some of the clinical studies reported good results when PRP was added to an autogenous bone graft. ${ }^{4-7}$ In all these studies, human PRP was used in variable concentrations. To test the validity of the addition of PRP to bone grafts, many experimental animal studies have been carried out, but the results of these studies are not consistent and contradic- tory outcomes have been reported. ${ }^{8-17} \mathrm{~A}$ minority of these studies showed a beneficial effect of PRP on the healing of bone defect. ${ }^{10,14,17}$ These results are certainly difficult to explain, particularly in the light of the mainly positive results of a large number of in vitro studies. To the best of our knowledge, 38 in vitro studies on the use of PRP have been published over the last 8 years. Of these 38 studies, 31 (81.5\%) (24 with human PRP and 7 with animal PRP) reported significant positive effects of PRP on the proliferation rate of osteoblasts or osteoblast-like cells and mesenchymal stem cells. ${ }^{1,18-47}$ In seven of these studies, a significant increase of the proliferation rate was observed when PRP was used in a relatively low concentration (range: $12 \times 10^{9}$ to $280 \times 10^{9} \mathrm{~L}^{-1}$ ). It was observed that higher concentrations of PRP caused a decrease in cell proliferation. ${ }^{23,26,28,33,34,41,46}$ Slapnicka et al. ${ }^{48}$ tested eight different concentrations of PRP (range: 0.38-2.86 times the baseline value) and found no significant positive effect on the proliferation rate of human osteoblasts. In eight

This work was performed at the Department of Biomaterials, Radboud University Nijmegen Medical Centre, Nijmegen, The Netherlands. Departments of ${ }^{1}$ Oral and Maxillofacial Surgery and ${ }^{2}$ Biomaterials, Radboud University Nijmegen Medical Centre, Nijmegen, The Netherlands.

*These two authors contributed equally to this work. 
studies, ${ }^{20,27,30-32,34,44,45}$ differentiation of the various cell types used was noted, but six other studies did not reveal any differentiation. ${ }^{21,36,39,40,43,47}$ In the studies mentioned, however, different experimental setups were used, that is, variation in cell origin, seeding density, temporal sampling, PRP preparation procedures, and platelet concentrations. Comparisons are, therefore, difficult to make and conclusions are impossible to draw. In addition, most studies draw conclusions from average PRP concentrations that were retrospectively calculated from the average baseline values. This is a meaningless exercise because there are variations in the baseline values and PRP concentrations. This effect can be enhanced by potential dose-dependent effects of PRP and its growth factors, which may vary for different animal species and even individual animals/humans.

To more precisely determine the efficacy of PRP, an in vitro study was designed to assess the effect of two concentrations of human PRP: one based on the average baseline platelet number and one on the maximum baseline platelet number. The target cells were rat osteoblast-like cells and human endothelial cells. Various osteogenic and angiogenic assays were performed with standardized PRP derivatives. The hypothesis was threefold:

- The concentration of growth factors increases with an increase of platelet number.

- Platelet concentrations of fivefold the average baseline value or fivefold maximum baseline value both affect target cell behavior.

- A platelet concentration of fivefold the maximum baseline value has a more profound effect on target cell behavior than a fivefold average baseline value.

\section{Materials and Methods}

\section{PRP preparation}

Human whole blood from 10 healthy male individuals was collected in sterile tubes with acid-citrate dextrose-A as an anticoagulant and platelet concentrates were prepared for clinical use by the Sanquin Blood Bank, Nijmegen, The Netherlands. The whole blood donated was processed, separating platelets from red blood cells and leucocytes by means of cytapheresis. Informed consent was obtained from all individuals to use the remnants of these platelet concentrates for the current in vitro study. By centrifugation and subsequent dilution, using the remnants of the platelet concentrates, from each donor two different PRPs were prepared, both representing a different (standard) concentration of platelets. Both PRPs were obtained independent of the individual baseline value of platelets. For the first PRP $\left(\mathrm{PRP}_{\text {low }}\right)$, it was the goal to achieve a platelet concentration of $\sim 1175 \times 10^{9} \mathrm{~L}^{-1}$, which is approximately five times the average number of platelets in peripheral human blood. For the second PRP ( $\left.\mathrm{PRP}_{\text {high }}\right)$, it was the goal to achieve a platelet concentration of $\sim 1750 \times 10^{9} \mathrm{~L}^{-1}$, which is approximately five times the maximum number of platelets in peripheral human blood. The platelet numbers in the PRPs and in whole blood were counted automatically by a hematology analyzer (ADVIA120; Siemens Healthcare Diagnostics). The PRPs and whole blood were then activated by adding calcium chloride and Fibriquik ${ }^{\mathrm{TM}}$ (Thrombin Reagent; bioMerieux, Inc.) to the blood product in the ratio $1: 1: 6(\mathrm{v} / \mathrm{v} / \mathrm{v})$, following the manufacturer's protocol. Clots were allowed to retract for $30 \mathrm{~min}$. After that, a centrifugation step was carried out at $4000 \mathrm{rpm}$ for $10 \mathrm{~min}$ at $22^{\circ} \mathrm{C}$ to separate the supernatant, containing the growth factors, from the aggregated platelets. The supernatants were stored at $-80^{\circ} \mathrm{C}$. The supernatant of both PRPs was called PRP-derivative low $_{\text {and }}$ PRP-derivative ${ }_{\text {high }}$, respectively.

\section{Determination of growth factor levels}

Samples of all 10 donors (whole blood and prepared PRP derivatives) were subjected to enzyme-linked immunosorbent assays (ELISAs; Quantikine ${ }^{\circledR} ;$ R\&D Systems Europe Ltd.) for measuring the amount of human platelet-derived growth factor (PDGF)-AA, PDGF-AB, PDGF-BB, transforming growth factor-beta 1 (TGF- $\beta 1$ ), insulin-like growth factorI (IGF-I), and vascular endothelial growth factor (VEGF). The immunoassays were performed following the manufacturer's instructions and the minimal detectable dose of these growth factors with the used ELISA test were PDGF-AA $2.29 \mathrm{pg} / \mathrm{mL}$, PDGF-AB $1.7 \mathrm{pg} / \mathrm{mL}$, PDGF-BB $<15 \mathrm{pg} / \mathrm{mL}$, TGF- $\beta 14.61 \mathrm{pg} / \mathrm{mL}$, IGF-I $0.026 \mathrm{ng} / \mathrm{mL}$, and VEGF $<9.0 \mathrm{pg} /$ $\mathrm{mL}$. All samples were analyzed in duplicate, after which the absorbance was measured at $450 \mathrm{~nm}$ (EL800 Universal Microplate Reader; Bio-Tek Instrument, Inc.).

\section{Osteoblast-like cell culture experiment}

Cell isolation and culture. Rat bone marrow cells were isolated and cultured using the method described by Maniatopoulos et al. ${ }^{49}$ Briefly, the two femora of a male Wistar rat (40-43 days old) were retrieved and washed in wash medium ( $\alpha$-modified Eagle's medium [ $\alpha$-MEM]; Gibco BRL, Life Technologies B.V. Breda) supplemented with $0.5 \mathrm{mg} / \mathrm{mL}$ gentamycin and $3 \mu \mathrm{g} / \mathrm{mL}$ fungizone (Sigma-Aldrich). Epiphyses were cut off and diaphyses were flushed with $10 \mathrm{~mL}$ of osteogenic medium ( $\alpha$-MEM, supplemented with $10 \%$ fetal calf serum [Gibco BRL, Life Technologies B.V. Breda], $50 \mu \mathrm{g} / \mathrm{mL}$ ascorbic acid [Sigma-Aldrich], $10 \mathrm{mM} \beta$ glycerophosphate, $10^{-8} \mathrm{M}$ dexamethasone [Sigma-Aldrich], and $50 \mu \mathrm{g} / \mathrm{mL}$ gentamycin). The isolated cells were cultured in osteogenic medium in three $75 \mathrm{~cm}^{2}$ culture flasks (Greiner Bio-one $\mathrm{GmbH}$ ) in a humidified atmosphere of $95 \%$ air and $5 \% \mathrm{CO}_{2}$ at $37^{\circ} \mathrm{C}$ (IG 650/750; JOUAN S.A.). The osteogenic medium was changed every 2 or 3 days. After 7 days of preculture, the obtained osteoblast-like cells were used for the cell culture experiments, which was carried out in two independent runs in triplicate $(n=3)$. For each run, freshly isolated cells were used.

Cell seeding. After 7 days of primary culture in osteogenic medium, the osteoblast-like cells were trypsinized, harvested, counted, and finally seeded in 24-well plates at a concentration of 10,000 cells $/ \mathrm{cm}^{2}$. Four experimental conditions were created:

1. Negative control (basic medium: $\alpha-\mathrm{MEM}+10 \%$ fetal calf serum + gentamycin);

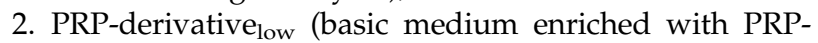
derivative low $_{\text {; }}$;

3. PRP-derivative ${ }_{\text {high }}$ (basic medium enriched with PRPderivative $\left._{\text {high }}\right)$;

4. Positive control (osteogenic medium). 
The PRP derivatives used in the cell culture experiment consisted of volumetrically pooled PRP derivatives of the individual donors to assure sufficient volumes for stimulation in the cell culture experiments. Addition of PRP derivatives was carried out at days 1,4 , and 7 after cell seeding by adding $10 \mathrm{vol} \%(\mathrm{v} / \mathrm{v})$ of the respective PRP derivative to basic medium. This procedure allows potential stimulation of the cells by the PRP derivatives for a period of up to 10 days. Cells were cultured in a humidified atmosphere of $95 \%$ air and $5 \% \mathrm{CO}_{2}$ at $37^{\circ} \mathrm{C}$, with three medium refreshments per week.

Cell proliferation. Cell proliferation was measured by determination of cellular protein content in individual wells $(n=3)$ for each experimental group. At 4, 8, 12, 16, and 24 days postseeding, the medium was removed and the cells were washed with phosphate-buffered saline (PBS; pH 7.4). Subsequently, $1 \mathrm{~mL}$ milliQ was added. Samples were frozen and thawed for three repetitive cycles, after which the cellular protein content was determined using a micro bicinchoninic acid (BCA) protein assay (Pierce) according to the instructions of the manufacturer.

Alkaline phosphatase analysis. Alkaline phosphatase (ALP) activity was measured as a marker for early differentiation of osteoblast-like cells using the same samples $(n=3)$ as for the proliferation assay according to a previously described method.$^{50}$ A volume of $80 \mu \mathrm{L}$ of sample or standard and $20 \mu \mathrm{L}$ of buffer solution $\left(5 \mathrm{mM} \mathrm{MgCl}_{2}, 0.5 \mathrm{M}\right.$ 2-amino-2-methyl-1-propanol) was pipetted into a 96-well plate (Greiner Bio-One) in duplicate and $100 \mu \mathrm{L}$ of substrate solution ( $5 \mathrm{mM}$ paranitrophenylphosphate) was added to each well. Subsequently, the plate was incubated for $1 \mathrm{~h}$ at $37^{\circ} \mathrm{C}$, after which the reaction was stopped by adding $100 \mu \mathrm{L}$ of $0.3 \mathrm{M} \mathrm{NaOH}$. Serial dilutions of 4-nitrophenol (final concentrations: $0-25 \mathrm{nM}$ ) were used for the standard curve. The plate was read in an ELISA reader at $405 \mathrm{~nm}$.

Calcium content. The deposition of calcium was used as a marker of late differentiation of osteoblast-like cells. The amount of calcium deposited after 4, 8, 12, 16, and 24 days of cell culture was measured by the orthocresolphthalein complexone (OCPC) method (Sigma), as described previously. ${ }^{51}$ Briefly, the cells were washed twice using PBS, after which $1 \mathrm{~mL}$ of $0.5 \mathrm{~N}$ acetic acid was added to each of three wells per experimental group $(n=3)$. After overnight incubation on a shaking apparatus, $300 \mu \mathrm{L}$ working solution was added to $10 \mu \mathrm{L}$ sample of standard in a 96-well plate (Greiner). Working solution consisted of (a) OCPC solution $(80 \mathrm{mg}$ OCPC in $75 \mathrm{~mL}$ milliQ $+0.5 \mathrm{~mL}$ of $1 \mathrm{M} \mathrm{KOH}+0.5 \mathrm{~mL}$ of $0.5 \mathrm{~N}$ acetic acid), (b) $14.8 \mathrm{M}$ ethanolamine/boric acid buffer (pH 11), (c) 8-hydroxyquinoline $(1 \mathrm{~g}$ in $20 \mathrm{~mL}$ of $95 \%$ ethanol), and (d) milliQ, in a ratio of 5:5:2:88 (a:b:c:d). A standard curve was generated by preparing serial dilutions of $\mathrm{CaCl}_{2}$ (range: $0-100 \mu \mathrm{g} / \mathrm{mL}$ ).

Morphological analysis. Scanning electron microscopy (SEM) was used to analyze cell morphology. For this purpose, cells were seeded on Thermanox ${ }^{\circledR}$ coverslips (13 mm diameter [dia]) in 24-well plates. Samples $(n=2)$ were prepared after 4 and 16 days of cell culture by washing twice with PBS, incubation in glutaraldehyde $(2 \%)$ for $10 \mathrm{~min}$, washing with $0.1 \mathrm{M}$ cacodylate buffer, and incubation in a graded series of ethanol for dehydration. Finally, the samples were dried with tetramethylsilane (ACROS organics), sputter-coated with gold, and analyzed using a JEOL 6310 SEM.

\section{Endothelial cell culture experiment}

Culture of endothelial cells. Human umbilical vein endothelial cells (HUVECs) were obtained cryopreserved from $\mathrm{BD}^{\mathrm{TM}}$ Biosciences (BD ${ }^{\mathrm{TM}}$ Biosciences Discovery Labware). Cells were cultured in $75 \mathrm{~cm}^{2}$ culture flasks in Medium-200 (Cascade Biologics) supplemented with low serum growth factors (containing $1 \mathrm{mg} / \mathrm{mL}$ hydrocortisone, $1.5 \mu \mathrm{g} / \mathrm{mL}$ basic fibroblast growth factor, $5 \mathrm{mg} / \mathrm{mL}$ heparin, $100 \mu \mathrm{g} / \mathrm{mL}$ bovine serum albumin, gentamycin/amphotericin B, $5 \mu \mathrm{g} /$ $\mathrm{mL}$ epidermal growth factor, and $2 \%$ fetal bovine serum) and incubated in a humidified atmosphere of $95 \%$ air and 5\% $\mathrm{CO}_{2}$ at $37^{\circ} \mathrm{C}$ until $80 \%$ confluence.

Tube-formation assay. The effect of various dilutions of the PRP derivates on the tube-formation capacity of HUVECs (BD Biosciences Discovery Labware) was studied using a commercially available tube-formation assay (BD BioCoat ${ }^{\mathrm{TM}}$ Angiogenesis Plates, 96-well format; BD Biosciences Discovery Labware) and HUVECs of passage 2 or 3 . The assay was performed following manufacturer's instructions (Guidelines for Use, BD BioCoat Angiogenesis System Endothelial Cell Tube Formation, Version 3.0), except for the staining and measuring. HUVECs were seeded at $20 \times 10^{3}$ cells/well, and the experimental conditions enrolled in the tube-formation assay consisted of increasing volume \% of pooled PRP derivatives. On the basis of the results of a preliminary experiment with range $5 \%-50 \%(\mathrm{v} / \mathrm{v})$, which revealed a significant decrease of tube formation when the volume $\%$ was $>20 \%$, a range of $2 \%-20 \%$ was used to obtain more detailed information about the most effective concentration(s). The positive control consisted of VEGF-supplemented medium $(20 \mathrm{ng} / \mathrm{mL}$; recombinant rat VEGF, rrVEGF 164 ; Department of Biochemistry, Radboud University Nijmegen Medical Centre, Nijmegen, The Netherlands). The plates were incubated in a humidified atmosphere of $95 \%$ air and $5 \% \mathrm{CO}_{2}$ at $37^{\circ} \mathrm{C}$ for $18 \mathrm{~h}$. Following incubation, the medium was carefully removed from the plates and the plates were washed twice with Hank's balanced salt solution containing $\mathrm{CaCl}_{2}$ and $\mathrm{MgCl}_{2}$ $\left(\mathrm{Gibco}^{\circledR}\right.$, Invitrogen $\left.{ }^{\mathrm{TM}}\right)$ by adding $100 \mu \mathrm{L}$ of this solution to each well. Subsequently, digital images were made of each well using a Leica DC-200 digital camera (LEICA Microscopy Systems Ltd.) mounted on a Leica Leitz DM IL microscope (Leica Mikroskopie \& Systeme $\mathrm{GmbH}$ ) at a magnification of $40 \times$ (Leica 519750 Periplan 10×/18 and Leitz Wetzlar 519759 EF 4/0.12). Images were analyzed manually with Leica QWin software (Leica Microsystems) for the parameters "total tube length" and "number of connections." The tube-formation assay was carried out with at least five samples per experimental group $(n=5)$.

\section{Statistical analysis}

Results of the platelet count and cell culture experiment were statistically evaluated using one-way analysis of variance, followed by post-hoc Tukey-Kramer multiple comparisons test. Results of the tube-formation assay were statistically evaluated, using one-way analysis of variance, followed by post-hoc Dunnett multiple comparisons test. The 
significance level for both tests was set at $p<0.05$. Calculations were performed in GraphPad Instat, Version 3.05 (GraphPad Software).

\section{Results}

\section{PRP characterization}

Platelet counts. Platelet counts of whole blood and both PRPs of each individual donor are depicted in Table 1. Platelet counts in whole blood ranged from 116 to $462 \times 10^{9} \mathrm{~L}^{-1}$, with an average of $236 \pm 98 \times 10^{9} \mathrm{~L}^{-1}$. Platelet counts of both PRPs were significantly higher compared with whole blood $(p<0.001): \mathrm{PRP}_{\text {low }}$ averaged $1181 \pm 104 \times 10^{9} \mathrm{~L}^{-1}$ (range: 971-1351 $\left.\times 10^{9} \mathrm{~L}^{-1}\right) ; \mathrm{PRP}_{\text {high }}$ averaged $1879 \pm 125 \times 10^{9} \mathrm{~L}^{-1}$ (range: $1780-2072 \times 10^{9} \mathrm{~L}^{-1}$ ). Platelet counts in $\mathrm{PRP}_{\text {high }}$ were also significantly higher compared with $\mathrm{PRP}_{\text {low }}(p<0.001)$.

Growth factor levels. Levels of various growth factors (PDGF-AA, PDGF-AB, PDGF-BB, TGF- $\beta 1$, IGF-I, and VEGF) were measured using ELISA. The mean growth factor levels (averaged from the levels of each individual donor) in whole blood and both PRP derivatives are presented in Figure 1. All measurements were above the detection limits.

Significant differences were observed for both PRP derivatives compared with whole blood for PDGF-AA (PRPderivative $_{\text {low }}: p<0.01$; PRP-derivative high $\left.: p<0.001\right)$, PDGF-AB $(p<0.01)$, and TGF- $\beta 1 \quad(p<0.001)$. Additionally, PRPderivative $_{\text {high }}$ showed significantly higher levels of VEGF compared with whole blood $(p<0.01)$. For PDGF-BB and IGF-I, no statistically significant differences were measured between the three different groups $(p>0.05)$. No significant differences were observed between both PRP derivatives.

\section{Cell culture experiment-osteoblast-like cells}

Two separate runs of the cell culture experiment with primary osteoblast-like cells were carried out, which showed

Table 1. Platelet Counts $\left(\times 10^{9} / \mathrm{L}\right)$ for Each Human Donor $(N=10)$ in Whole Blood and Both Platelet-Rich Plasmas (Platelet-Rich Plasma low and Platelet-Rich Plasma Pigh $_{\text {) }}$ )

\begin{tabular}{lccc}
\hline & \multicolumn{3}{c}{ Platelet } \\
\cline { 2 - 4 } Donor & Whole blood & PRP $P_{\text {low }}\left(\times 10^{9} \mathrm{~L}^{-1}\right)$ \\
\hline 1 & 204 & 1111 & $P R P_{\text {high }}$ \\
2 & 275 & 971 & 1741 \\
3 & 146 & 1230 & 1926 \\
4 & 203 & 1226 & 2072 \\
5 & 116 & 1224 & 2006 \\
6 & 223 & 1215 & 1833 \\
7 & 462 & 1351 & 1780 \\
8 & 225 & 1151 & Unknown \\
9 & 185 & 1153 & 1796 \\
10 & 316 & Unknown & Unknown \\
\hline Mean & 236 & 1181 & 1879 \\
SD & 98 & 104 & 125 \\
\hline
\end{tabular}

Mean and standard deviation (SD) are given at the end of the table. The mean platelet counts for the three preparations are significantly different $(p<0.001)$.

PRP, platelet-rich plasma. similar results for proliferation, differentiation, mineralization, and morphology. The details of one representative run are presented below.

Proliferation. Total cellular protein levels were measured after 4, 8, 12, 16 and 24 days of culture (Fig. 2). Compared with the positive controls, PRP-derivative supplementation significantly increased cell proliferation at day $12(p<0.001)$, day 16 (PRP-derivative low: $\quad p<0.05 ;$ PRP-derivative ${ }_{\text {high }}$ : $p<0.01)$, and day $24(p<0.001)$. In contrast, negative controls showed significantly decreased cell proliferation at day $8(p<0.001)$ and significantly increased cell proliferation at day $24(p<0.001)$ compared with positive controls.

Differentiation. ALP activity was measured as a marker for osteoblast-like cell differentiation (Fig. 3). Compared with positive controls, PRP-derivative supplementation significantly decreased ALP activity at day $12(p<0.001)$ and day 24 (PRP-derivative low $: p<0.01$; PRP-derivative high $: p<0.001$ ). Negative controls showed significantly decreased ALP activity at day $24(p<0.01)$ compared with positive controls.

Mineralization. The deposition of calcium in the mineralized extracellular matrix by primary rat osteoblast-like cells was used as a late marker of differentiation (Fig. 4). Compared with positive controls, PRP-derivative supplementation significantly decreased mineralization at day 16 $(p<0.01)$ and day $24 \quad(p<0.001)$. Additionally, negative controls showed significantly decreased mineralization at day $16(p<0.01)$ and day $24(p<0.001)$ compared with positive controls.

Morphology analysis. After 4 and 16 days, the morphological appearance of the different experimental cell cultures were analyzed using SEM. At day 4, no calcium deposition could be seen for all groups. Osteoblast-like cells were covering parts of the surface. At day 16, calcium deposition could be seen in the positive control groups in the form of mineralized nodules. Some collagen bundles were also seen in this group. Both PRP-derivative supplemented groups showed calcium deposition, though substantially less compared with the positive control group. Moreover, no apparent differences in calcium deposition could be seen between the two PRP-derivative-supplemented groups. In the negative control group, no mineralized nodules could be observed. Electron microscopy images from day 16 are depicted in Figure 5.

\section{Cell culture experiment-endothelial cells}

Primary HUVECs were cultured with supplementation of VEGF (20 ng/mL; control) or PRP derivatives (various volume \%; range: $2 \%-20 \%$ ). Different volumes of PRP derivatives cause dilutions corresponding to different concentrations of platelets per experimental group $\mathrm{PRP}_{\text {low }}$ and $\mathrm{PRP}_{\text {high }}$, respectively (Table 2 ). After $18 \mathrm{~h}$ of incubation, light microscopy images were obtained (Fig. 6), which were subsequently used to determine the parameters "tube length" and "number of connections."

Tube length. Compared with controls, supplementation of $2 \%-8 \%$ PRP derivative significantly increased tube length 


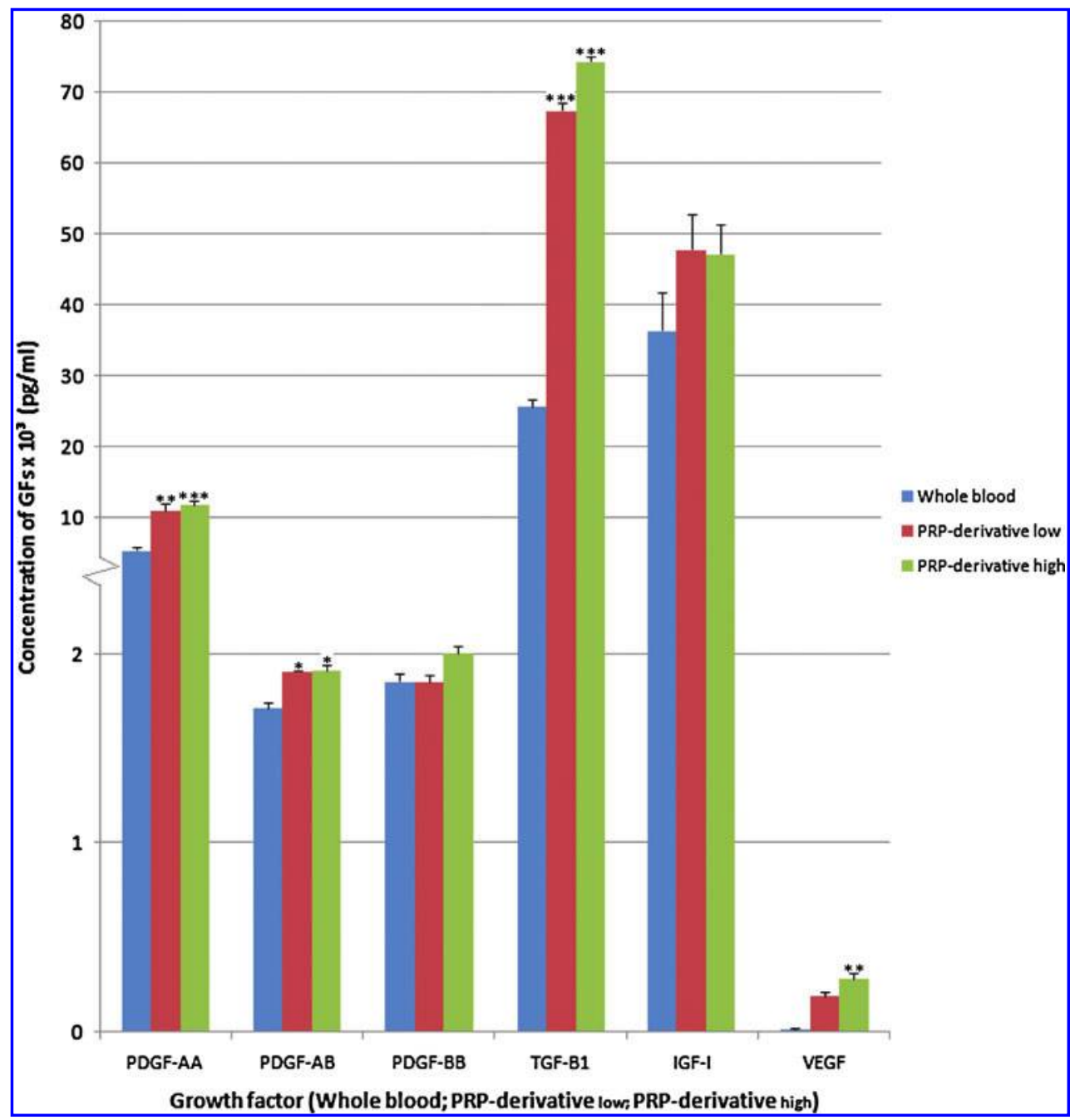

FIG. 1. Concentration of growth factors $\left(\times 10^{3} \mathrm{pg} /\right.$ $\mathrm{mL})$ PDGF-AA, PDGF-AB, PDGF-BB, TGF- $\beta 1$, IGF-I, and VEGF in human PRP derivatives. Bars represent means $\pm S D$ of triplicate samples. * $p<0.05$, ${ }^{* *} p<0.01$, and ${ }^{* * *} p<0.001$ compared with whole blood. PDGF, plateletderived growth factor; TGF- $\beta 1$, transforming growth factor-beta 1; IGF-I, insulin-like growth factor-I; VEGF, vascular endothelial growth factor; PRP, platelet-rich plasma; SD, standard deviation. Color images available online at www.liebertonline.com/ ten.

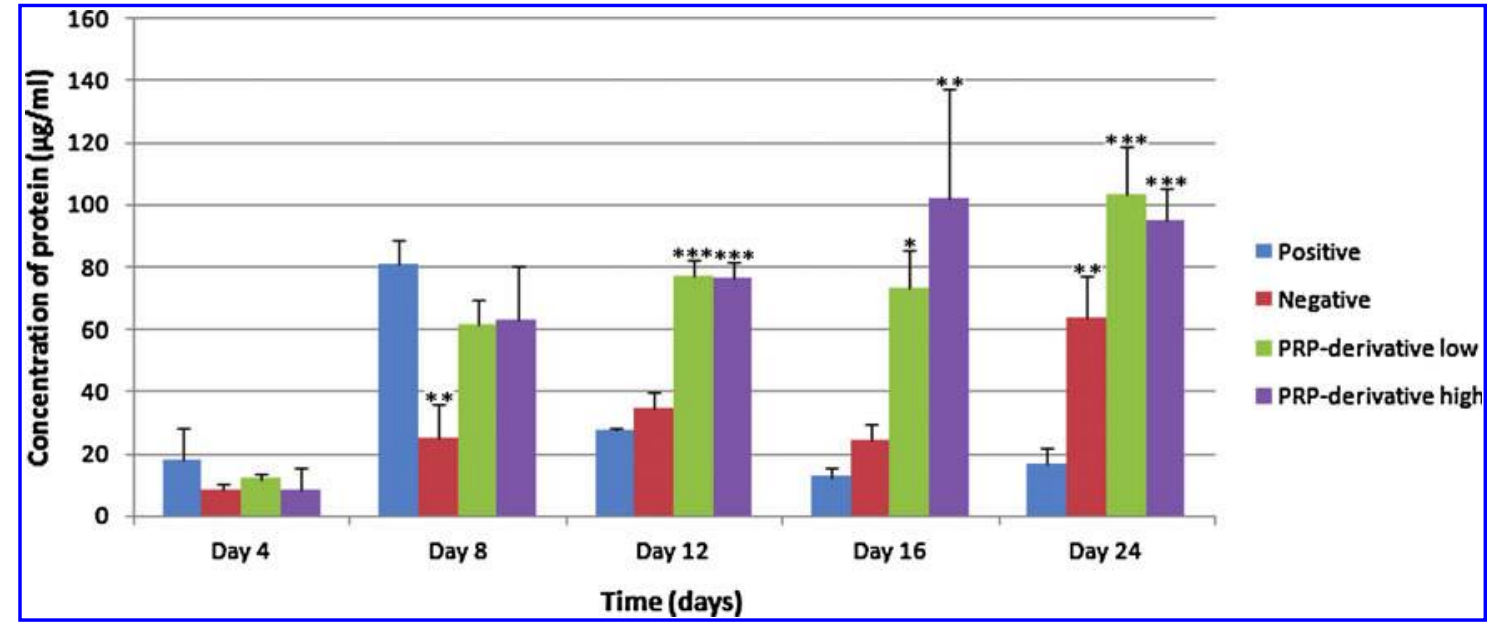

FIG. 2. Cellular protein concentrations $(\mu \mathrm{g} / \mathrm{mL})$ in primary rat osteoblast-like cell cultures for positive controls (osteogenic medium), negative controls (basic medium), and PRP-derivative-supplemented media. Bars represent mean $\pm \mathrm{SD}$ of triplicate samples. ${ }^{*} p<0.05,{ }^{* *} p<0.01$, and ${ }^{* * *} p<0.001$ compared with positive controls. Color images available online at www .liebertonline.com/ten. 


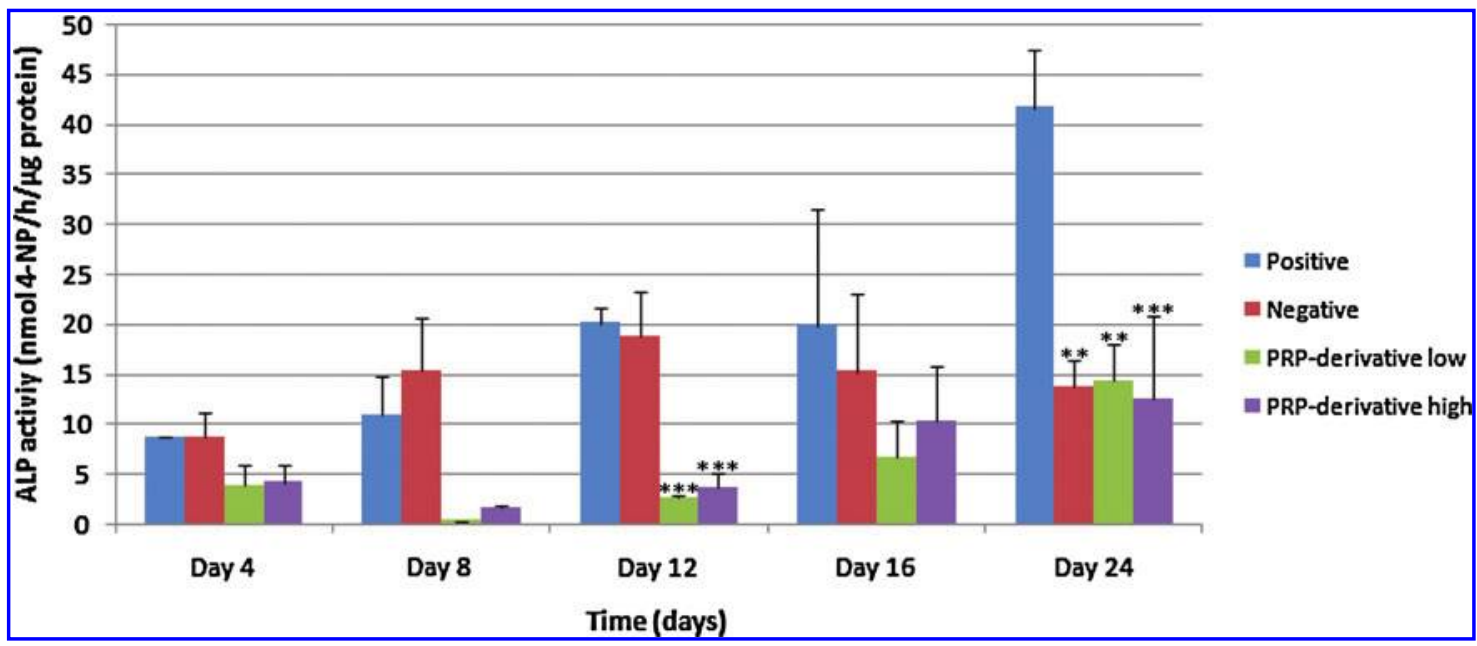

FIG. 3. ALP activity (nmol 4-NP per hour per $\mu$ g cellular protein) in primary rat osteoblast-like cell cultures for positive controls (osteogenic medium), negative controls (basic medium), and PRP-derivative-supplemented media. Bars represent mean \pm SD of triplicate samples. ${ }^{* *} p<0.01$ and ${ }^{* * *} p<0.001$ compared with positive controls. ALP, alkaline phosphatase. Color images available online at www.liebertonline.com/ten.

FIG. 4. Calcium deposition $(\mu \mathrm{g} / \mathrm{mL})$ in primary rat osteoblast-like cell cultures for positive controls (osteogenic medium), negative controls (basic medium), and PRP-derivative-supplemented media. Bars represent mean $\pm \mathrm{SD}$ of triplicate samples. ${ }^{* *} p<0.01$ and $* * * p<0.001$ compared with positive controls. Color images available online at www.liebert online.com/ten

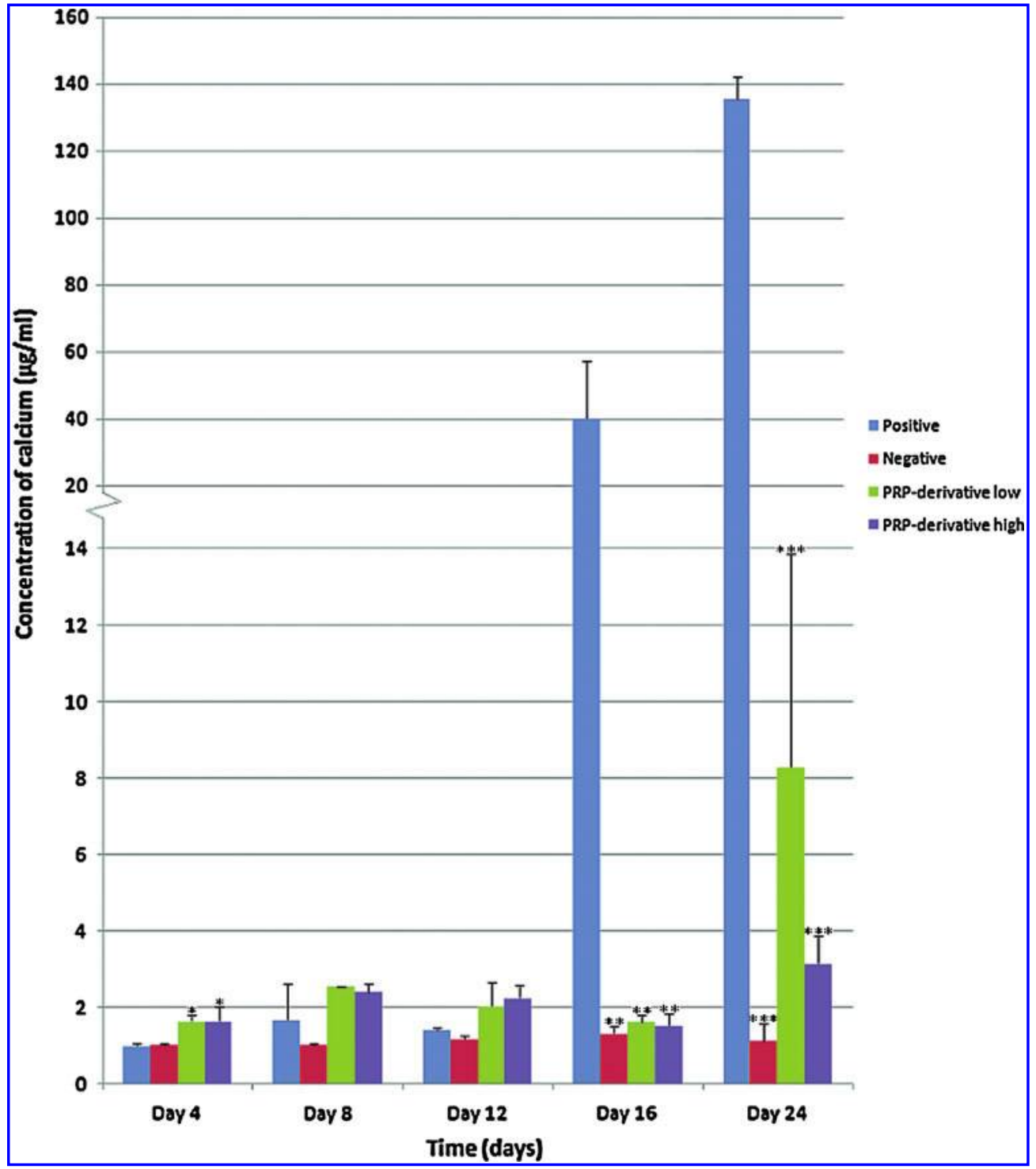



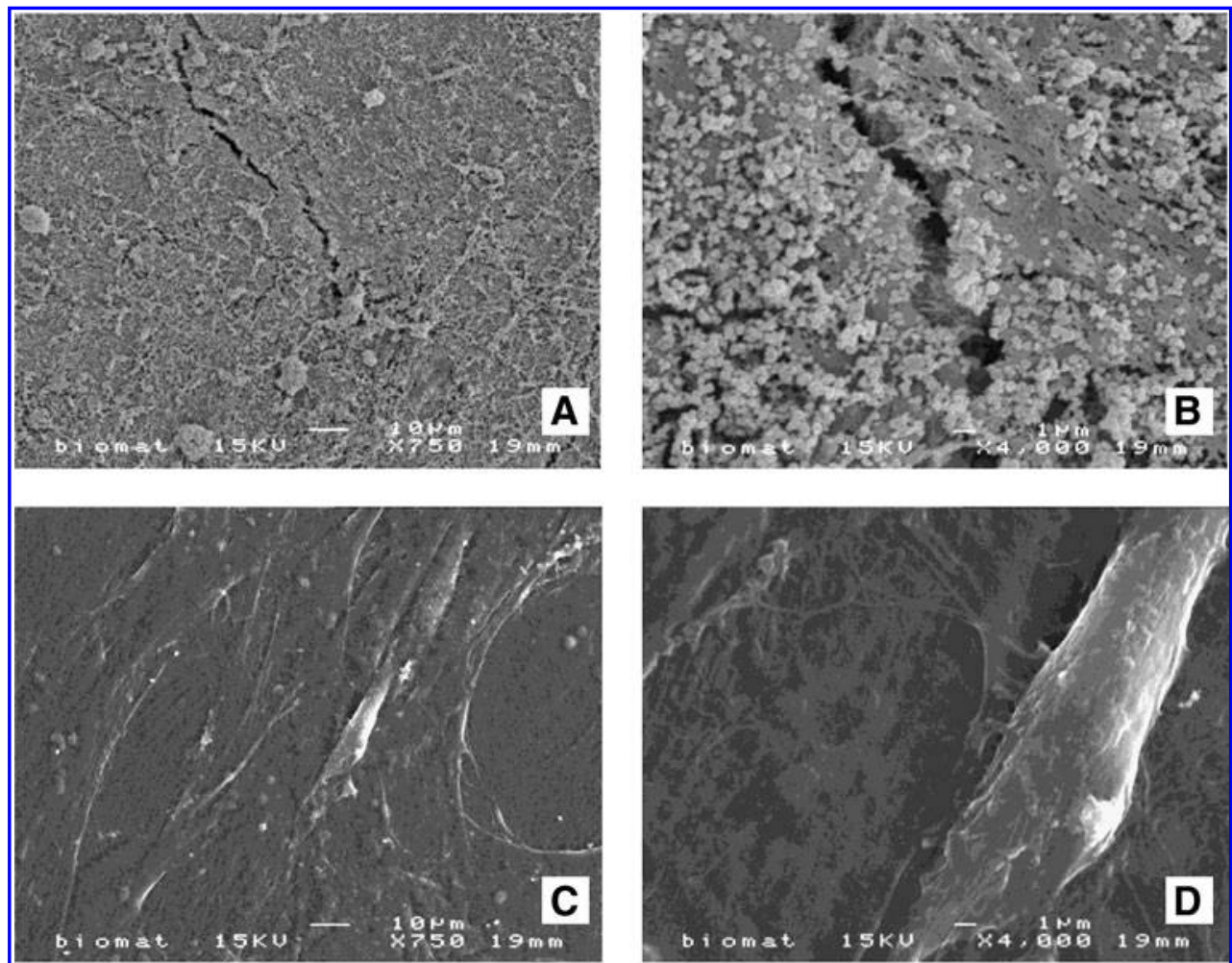

FIG. 5. Scanning electron micrographs of rat bone marrow cells at day 16 . Graphs are shown for the groups: positive controls
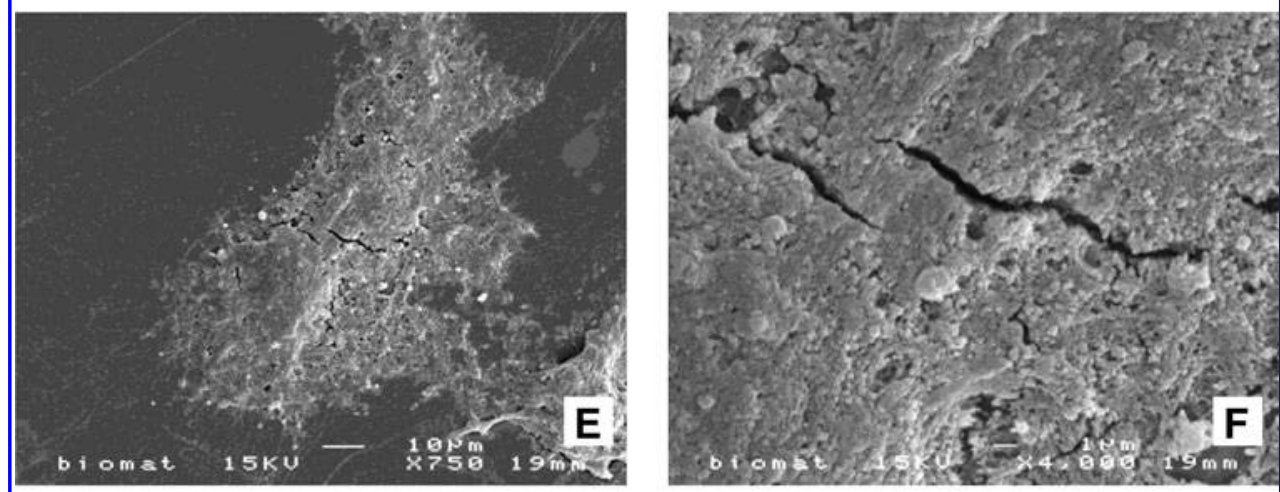
(A, 750×; B, 4000×), negative controls $($ C, 750×; D, 4000×), PRP-derivative ${ }_{\text {low }}(\mathrm{E}, 750 \times$; F, $4000 \times)$, PRP-derivative ${ }_{\text {high }}$ (G, 750×; H, 4000×).
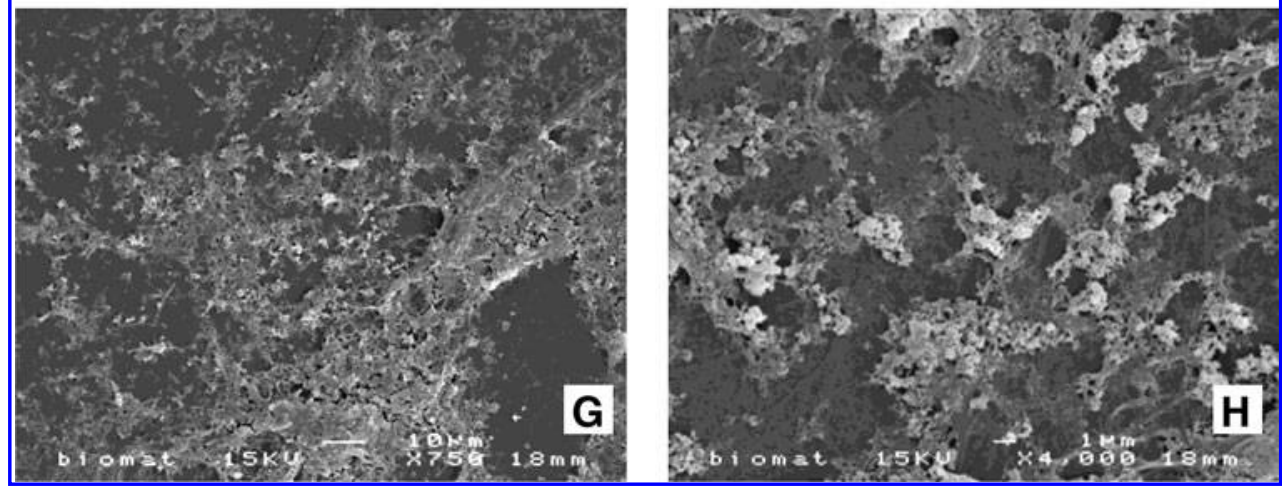

$(p<0.01$; Fig. 7). Supplementation with higher volume $\%$ $(>15 \%)$ of PRP derivatives showed to decrease tube length significantly $(p<0.01)$.

Number of connections. Compared with controls, supplementation of $2 \%-8 \%$ PRP derivatives significantly increased the number of connections of HUVECs $(p<0.01$; Fig. 8).
Supplementation of HUVECs with higher amounts showed no significant effect on the number of connections $(p>0.05)$.

\section{Discussion}

The aim of this study was to evaluate the effects of two standardized and significantly different groups of PRP from 
Table 2. Different Volumes of Platelet-Rich Plasma Derivatives Causes Dilution Corresponding with Different Concentrations of Platelets PER EXPERIMENTAL GROUP

\begin{tabular}{|c|c|c|}
\hline \multirow{2}{*}{$\begin{array}{l}\text { Microliters of PRP derivative } \\
\text { per } 100 \mu \mathrm{L} \text { of cell suspension } \\
(\text { volume \%) }\end{array}$} & \multicolumn{2}{|c|}{$\begin{array}{l}\text { Corresponding number } \\
\text { of platelets }\left(\times 10^{9} \mathrm{~L}^{-1}\right)\end{array}$} \\
\hline & $P R P_{\text {low }}$ & $P R P_{\text {high }}$ \\
\hline 2 & $23.5^{*}$ & $35^{*}$ \\
\hline 5 & $58.8^{*}$ & $87.5^{*}$ \\
\hline 8 & $94^{*}$ & $104^{*}$ \\
\hline 10 & 117.5 & 175 \\
\hline 12 & 141 & 210 \\
\hline 15 & 176.3 & 263 \\
\hline 18 & 211.5 & 315 \\
\hline 20 & 235 & 350 \\
\hline 30 & 352.5 & 525 \\
\hline 40 & 470 & 700 \\
\hline 50 & 587.5 & 875 \\
\hline $\begin{array}{l}\text { Peripheral blood; mean } \\
\text { [platelet] }\end{array}$ & \multicolumn{2}{|c|}{236} \\
\hline
\end{tabular}

Positive significant results of the experimental groups $\mathrm{PRP}_{\text {low }}$ and $\mathrm{PRP}_{\text {high }}$ in both tube-formation assays are indicated by an asterisk. ${ }^{*} p<0.01$ was found for each experimental group compared with control.

10 human donors on cellular behavior. The standardized PRPs used were fivefold average and fivefold maximum base line values of platelets in whole blood. These standardized PRPs were defined by determining platelet numbers and subsequently growth factor concentrations in the supernatant of activated PRP, called PRP derivatives. Subsequently, both PRP derivatives were used as an additive in cell culture assays using primary osteoblast-like cells or primary endothelial cells.

The hypothesis was threefold:

- The concentration of growth factors increases with an increase of platelet number.

- Platelet concentrations of fivefold the average baseline value or fivefold maximum baseline value both affect target cell behavior.

- A platelet concentration of fivefold the maximum baseline value has a more profound effect on target cell behavior than a fivefold average baseline value.

The results of this experiment reveal that the first and the third of the three hypotheses have to be rejected. The growth factors TGF- $\beta 1$ and PDGF (AA and AB) in both experimental PRP groups were significantly increased when compared with the whole blood, but no significant difference was seen between the two groups of PRP. The both increased concentrations of platelets, when compared with the whole blood, had a positive effect on the target cells. A platelet concentration of five times the maximum baseline value does not have a more profound effect on the target cells than a platelet concentration of five times the average baseline value.

\section{PRP characterization}

From the 38 in vitro studies performed on the use of PRP in the last 8 years, only Ishida et al. ${ }^{29}$ calculated the occurrence of a significant difference between the platelet number in the whole blood samples and their experimental PRP. In the majority of the other studies, however, no reference value of the whole blood platelet numbers was given, and therefore, the result presented in these studies are difficult to interpret. ${ }^{18,19,22,24,25,30-33,35,36,38,40,41,43,44,46,47,52-55}$ Also, in several studies, there is a great variation in the concentrations used, or only a mean multiplication factor has been mentioned without specification of the concentrations used, which makes comparisons almost meaningless. ${ }^{31,32,40,43,52,53}$

When carrying out studies on the effect of PRP, it is important that the variation of the concentration of the platelets in the various PRP groups is minimized. Especially, overlap of platelet concentrations of different groups of PRP and whole blood should be avoided when groups are to be compared. For this reason, it was the aim of the present study to compare the effect and the amount of growth factors of two groups of PRP, with significantly different concentrations of platelets between each group of PRP and whole blood.

According to Marx, ${ }^{56}$ in human beings, a sufficient cellular response to PRP is expected when a four- to fivefold increase over whole blood platelet numbers is achieved. However, he did not make it clear, whether this concerns the individual, the average, or the maximum value of the whole blood platelet number. For this reason, it was the purpose of the present study to compare PRP with a four- to fivefold average $\left(\mathrm{PRP}_{\text {low }}\right)$ and a four- to fivefold maximum platelet number $\left(\mathrm{PRP}_{\text {high }}\right)$, independent of the individual baseline concentration of the donors.

The results of the platelet count showed statistically significant differences between whole blood (mean value: $236 \pm$ $98 \times 10^{9}$ platelets/L), $\mathrm{PRP}_{\text {low }}$ (mean value: $1181 \pm 104 \times 10^{9}$ platelets/L), and $\mathrm{PRP}_{\text {high }}$ (mean value: $1879 \pm 125 \times 10^{9}$ platelets/L). This implies that a concentration of fivefold average platelet numbers $\left(\mathrm{PRP}_{\text {low }}\right)$ and a concentration of fourfold maximum platelet numbers $\left(\mathrm{PRP}_{\text {high }}\right)$ were obtained. Unfortunately, the volume of the blood samples used was not enough to prepare a third group of PRP with a fourto fivefold individual baseline platelet number. This was due to the fact that the selected donors gave blood for clinical use and we were only allowed to use the remnants of the prepared platelet concentrates.

Regarding the growth factor concentrations, the results of this study showed a statistically significant difference in the concentrations of PDGF-AA, PDGF-AB, and TGF- $\beta 1$ between both PRP derivatives and whole blood. Only in the PRP-derivative ${ }_{\text {high }}$ group, the concentration of VEGF showed a significant higher level when compared with whole blood. No significant differences were observed between the levels of the growth factor concentrations of the two PRP derivatives.

A large variation in PRP growth factor concentration has been reported by several authors. ${ }^{27,32,57,58}$ Compared with the present study, Kilian et al. ${ }^{32}$ reported on similar results for TGF- $\beta 1$ (PRP platelet numbers: $1021.9 \pm 345.9 \times 10^{9} \mathrm{~L}^{-1}$ ). This was not the case for the level of PDGF-AB, which was much higher $(162,164 \mathrm{pg} / \mathrm{mL})$, and the levels of PDGF-AA $(639 \mathrm{pg} / \mathrm{mL})$ and PDGF BB $(578 \mathrm{pg} / \mathrm{mL})$ were substantially lower than that in the present study. The level of VEGF was found to be not detectable. Han et al. ${ }^{27}$ showed higher levels of PDGF-AB (>100 ng/mL) and TGF- $\beta 1$ (>400 ng/mL) with 

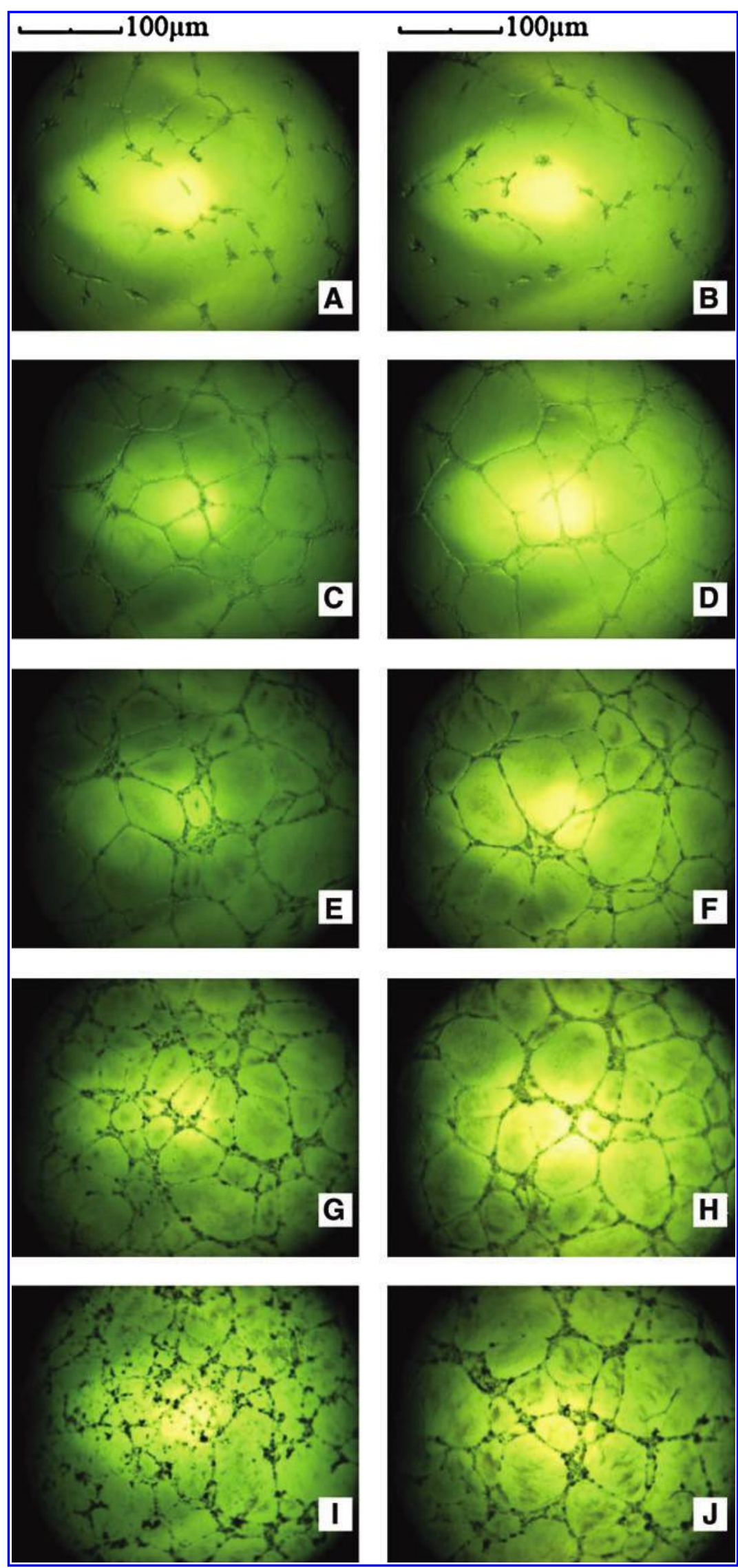

FIG. 6. Tube-like structures are shown for the groups: control with VEGF (A, B), PRP-derivative low $2 \%($ C), PRP-deriva-

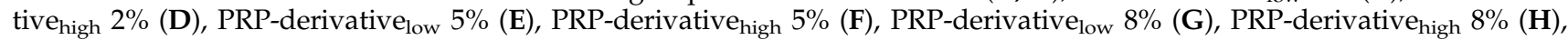
PRP-derivative $_{\text {low }} 10 \%(\mathrm{I})$, and PRP-derivative ${ }_{\text {high }} 10 \%(\mathrm{~J})$. Color images available online at www.liebertonline.com/ten. 


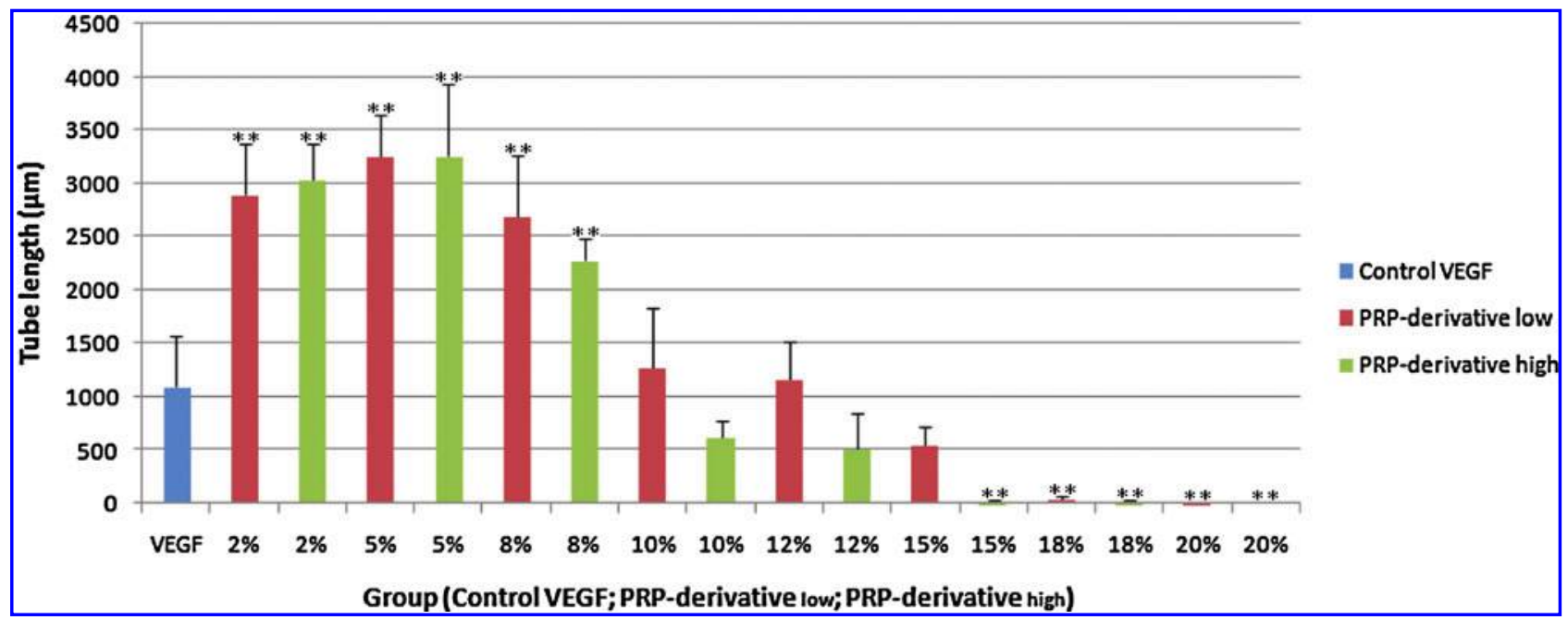

FIG. 7. Tube length $(\mu \mathrm{m})$ of human umbilical vein endothelial cells, supplemented with VEGF (20 ng/mL; control) or PRP derivative (various volume $\%$; range: $2 \%-20 \%$ ). Bars represent mean \pm SD of at least five samples. ${ }^{* *} p<0.01$ compared with controls. Color images available online at www.liebertonline.com/ten.

PRP platelet numbers of $1511 \times 10^{9}$ and $1897 \times 10^{9} \mathrm{~L}^{-1}$, respectively. The levels of PDGF-AA and PDGF-BB were not measured. They reported on a dose-dependent stimulatory effect of TGF- $\beta 1$ on cell cultures. PRP with $50-100 \mathrm{ng} / \mathrm{mL}$ TGF- $\beta 1$ appeared to be an optimal concentration. In another study by Han et al., ${ }^{57}$ higher levels of PDGF-BB (18,000 pg/ $\mathrm{mL})$ and TGF- $\beta 1(100,000 \mathrm{pg} / \mathrm{mL})$ in PRP have been reported with an eightfold increase over baseline platelet value, whereas the level of VEGF $(245 \mathrm{pg} / \mathrm{mL})$ was similar to the present study. Unfortunately, these authors did not measure the levels of PDGF-AA and PDGF-AB. Huang et al. ${ }^{58}$ reported on higher levels of TGF- $\beta 1(8269.67 \mathrm{pg} / \mathrm{mL})$ and PDGF-AB $(86,449.48 \mathrm{pg} / \mathrm{mL})$, respectively, compared with the present study, when PRP with platelet numbers $1240 \times 10^{9} \mathrm{~L}^{-1}( \pm 159.72)$ was used. The levels of PDGF-AA and PDGF-BB were not measured. The level of VEGF $(192 \mathrm{pg} / \mathrm{mL})$, however, was somewhat lower than that in the present study.
In the aforementioned studies, ${ }^{27,32,57,58}$ as well as in the present study, human blood was collected in tubes with acidcitrate dextrose-A as an anticoagulant and the PRP was activated by adding a mixture of thrombin and calcium chloride. In one study, ${ }^{32}$ calcium gluconate instead of calcium chloride was used. The ratios of thrombin (bovine) and calcium chloride in these studies were comparable, but the amount of the added mixture to $1 \mathrm{~mL}$ PRP varied from 100 to $300 \mathrm{IU} / \mathrm{mL}$ PRP. There was no relation between the amount of the added mixture of thrombin and calcium chloride and the level of growth factor measured. The ELISA kits used to measure the levels of the growth factors were the same in all the aforementioned studies. The number of donors who gave blood differed: for example, 1 donor, ${ }^{32,57} 2$ donors, $^{27} 5$ donors, ${ }^{58}$ and 10 donors (the present study).

Apart from the number of the donors and the amount of thrombin added, the most variable parameter in all these studies is the variation in the concentration of the platelets

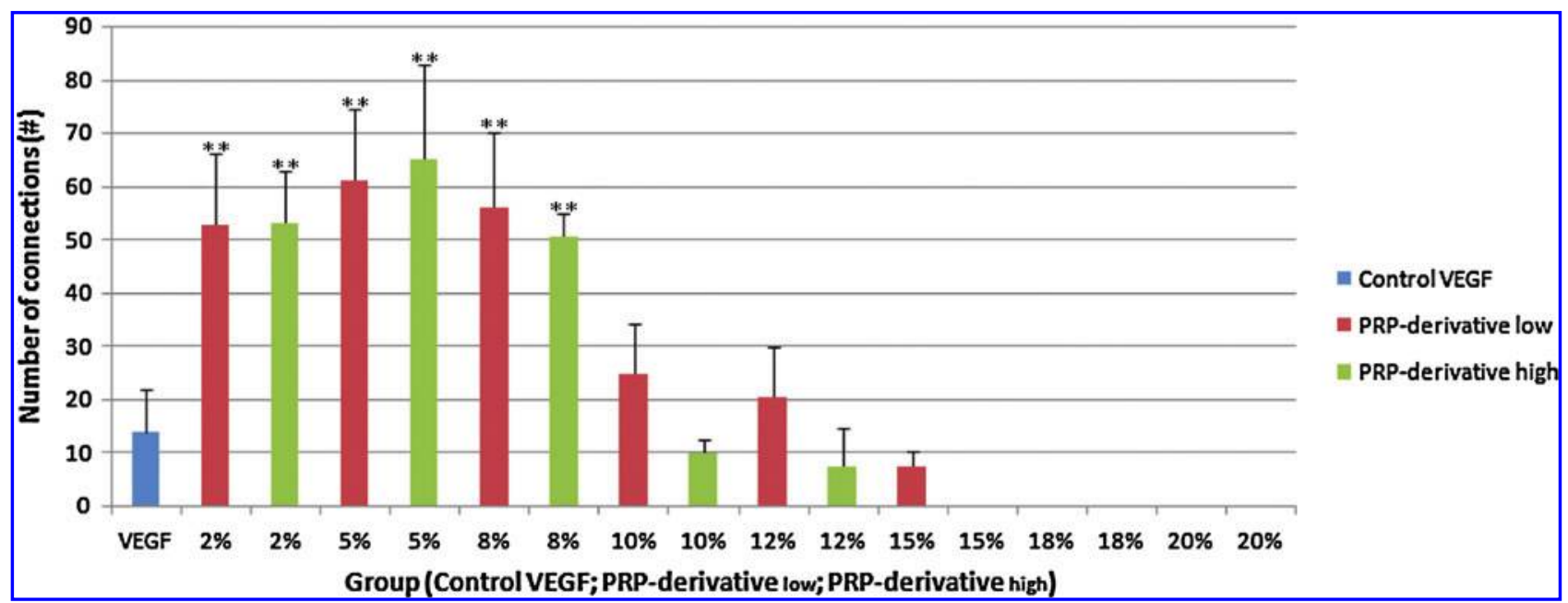

FIG. 8. Total number of connections formed by human umbilical vein endothelial cells, supplemented with VEGF (20 ng/ $\mathrm{mL}$; control) or PRP derivative (various volume \%; range: $2 \%-20 \%$ ). Bars represent mean \pm SD of at least five samples. ${ }_{* *}^{*} p<0.01$ compared with controls. Color images available online at www.liebertonline.com/ten. 
used. Whether this fully explains the variations of the levels of the growth factors measured, especially PDGF, remains to be investigated.

Roussy et al. ${ }^{42}$ showed that concentrations of growth factors are time dependent and reported on different concentrations after 0,1 , and $24 \mathrm{~h}$ and 6 days. Another influence of growth factor release is the $\mathrm{pH}$ of the environment. Liu et al $^{33}$ demonstrated that a low $\mathrm{pH}$ of 5.0 contained the highest PDGF concentration, but the lowest TGF- $\beta$ concentration. Other factors may be the number of freeze-thaw cycles of PRP and individual differences in growth factor release.

In the present study, a statistically significant difference in the number of platelets between all three groups was found. The concentration of growth factors (TGF- $\beta 1$, PDGF-AA, and $\mathrm{AB}$ ), however, differed only between the whole blood and each of the PRP derivatives, but not between the two PRP derivatives. This implies that there is no direct relation between an increase in the number of platelets and an increase in the amount of the growth factors released.

\section{Cell culture experiment-osteoblast-like cells}

The present study revealed that both PRP derivatives had a stimulatory effect on the late cell proliferation compared with positive controls (i.e., cell culture in osteogenic medium). There was, however, no significant difference between the two types of PRP derivatives. These results are in contrast to studies that reported on a dose-dependent effect of PRP on cell proliferation. ${ }^{1,22,25-27,29,31,33,35-37,40,41,43,44,46,52 ~ I t ~}$ needs to be emphasized, however, that comparison of the results of these reports is difficult because of differences in the origin of the cells and the performed experimental procedures. For instance, the used cells in these reports are either primary cells or cell lines and were treated to form different tissues (e.g., bone, connective tissue, periodontal ligament, cartilage), which implies that the susceptibility for components of the PRP is variable or even absent. Different PRP preparation methods and donor variability are also likely to influence growth factor levels within a PRP derivative, which makes comparisons of its biological effects between different experiments difficult. Also, cellular behavior commonly relies on a combination of factors, which makes comparisons for PRP derivatives with different levels of multiple growth factors extremely unreliable. In view of the studies reporting dose-dependent effects of PRP on cell proliferation, it needs to be mentioned that not all reports provide detailed information of the PRP that was added to the used cell culture medium. . $^{2,31,35,41,43,52}$

Several authors describe the use of $1 \%-30 \%(\mathrm{v} / \mathrm{v})$ PRP in cell culture experiments with stimulatory effects on cell proliferation. ${ }^{1,29,36,40}$ It is of interest that Weibrich et al., ${ }^{46}$ Choi et al., ${ }^{23}$ Pietramaggio et al., ${ }^{41}$ and $\mathrm{Hsu}$ et al. ${ }^{28}$ showed significant increase in cell proliferation when adding low volume percentages and a decrease in cell proliferation when adding high volume percentages of PRP. Weibrich et al. $^{46}$ and Choi et al. ${ }^{23}$ showed the highest increase in cell proliferation at $1 \%-5 \%$ PRP addition. Okuda et al. ${ }^{39}$ showed that PRP addition of $2 \%$ and $5 \%$ stimulated DNA synthesis in gingival fibroblasts, periodontal ligament cells, osteoblasts, and osteoblastic ligament cells. Similarly, Hsu et al. ${ }^{28}$ measured a significant increase in proliferation of human periodontal ligament cells on $2 \%$ and 5\% PRP gel and a significant decrease on $15 \%$ and $30 \%$ PRP gel. Considering the results mentioned, it appears that the concentrations used in the present study (corresponding to $107 \times 10^{9}$ platelets/L for $\mathrm{PRP}_{\text {low }}$ and $159 \times 10^{9}$ platelets/L for $\mathrm{PRP}_{\text {high }}$ ) were relatively high. Yet, the observed stimulation of the cell proliferation was obvious and similar for both PRP derivatives.

Results of the ALP activity analysis, a marker for early differentiation of osteoblast-like cells, showed the inability of PRP derivatives to induce osteoblast-like cell differentiation. These results are in keeping with the findings of Arpornmaeklong et al., ${ }^{21}$ Kanno et al., ${ }^{1}$ Ogino et al., ${ }^{36}$ van den Dolder et al., ${ }^{45}$ and Zaky et al., ${ }^{47}$ who all reported on a significant suppression of early differentiation by PRP. Some studies, however, reported on an early increase of ALP activity of periodontal ligament cells, osteoblasts, or adipose-derived stroma cells, respectively, when using PRP. ${ }^{20,27,31,34,44}$

The absence of mineralized matrix deposition within the extracellular matrix is the consequence of the lack of early osteoblast-like cell differentiation, as seen in the present study.

The calcium content of PRP-derivative-supplemented cultures was found to be permanently low, whereas positive controls (i.e., cultures in osteogenic medium) showed a profound increase in the latest stage of the culture. The observed ALP activity and calcium content are in keeping with the presence of mineralized nodules in positive controls, whereas these nodules were absent in PRP-derivativesupplemented cultures. Some authors, however, reported stimulation of early and late differentiation. ${ }^{30-32,44}$ Liu et al. ${ }^{34}$ demonstrated induction of early and late differentiation by PRP, whereas no osteogenic medium was added to the experimental PRP groups. van den Dolder et al. ${ }^{45}$ even showed a significant positive effect of PRP on the late differentiation of osteoblast-like cells (i.e., significant increase in calcium deposition after 8, 12, and 16 days), despite a negative effect of PRP on the ALP activity at days 4, 8 , and 12. The addition of PRP in their setup, however, was different from the one in the present study, that is, PRP coating versus PRP derivative addition to cell culture medium. The exact reason for this discrepancy remains unclear.

\section{Cell culture experiment-endothelial cells}

As there is hardly any information on the use of tubeformation assays to analyze the potential angiogenic effect of PRP, a commercially available method for screening angiogenesis $^{59}$ was used. In the present study, this method was applied with VEGF stimulation $(20 \mathrm{ng} / \mathrm{mL})$ as a positive control next to both PRP derivatives in different volume percentages.

The results of the tube-formation analysis showed significant effects on tube length and number of connections for $2 \%, 5 \%$, and $8 \%$ supplementation of both PRP derivatives compared with positive controls. The optimal volume percentage of PRP derivative was found to be $\sim 5 \%$ for each PRP derivative. The actual concentrations of growth factors in the cell medium of $5 \%$ for $\mathrm{PRP}_{\text {low }}$ or $\mathrm{PRP}_{\text {high }}$ corresponded with platelets numbers of $\sim 60 \times 10^{9}$ and $\sim 90 \times 10^{9} \mathrm{~L}^{-1}$, respectively (Table 2). Weibrich et al. ${ }^{46}$ and Choi et al. ${ }^{23}$ showed highest increase in cell proliferation at $58.9 \times 10^{9}$ platelets $/ \mathrm{L}$ 
and 12 to $62 \times 10^{9}$ platelets/L $(1 \%-5 \%)$, respectively. In both studies, however, different cells, that is, osteoblast-like cells and alveolar bone cells, were used, but no endothelial cells. At present, only two studies used PRP in combination with endothelial cell culture (HUVECs). ${ }^{60,61}$ Fréchette et al ${ }^{60}$ reported on a strong beneficial effect of PRP on the proliferation of human osteoblasts and endothelial cells (HUVECs). The authors found that the supernatants, which were obtained after activation of PRP by adding calcium chloride and thrombin, appear to be more mitogenic for HUVECs than for nonactivated PRP supernatants. In contrast, PRP activation had little additional benefit on osteoblast proliferation. The amount of calcium chloride and thrombin added, revealed to be of influence on the proliferation, but the authors concluded that additional experiments are needed to determine which concentrations are optimal for bone formation in vivo.

Based on the results from in vitro vasculogenesis of endothelial cells, Hofmann et al. ${ }^{61}$ created a long-term coculture model of HUVECs and primary human osteoblasts employing polyurethane and PRP in a static microenvironment. The authors concluded that growth factors released from PRP are likely to provide additional stimulation for growth and maturation of HUVECs. The results of the current study are in accordance with this conclusion, since both PRPderivatives showed improved tube formation compared to VEGF alone, even within 16-18 h.

\section{Conclusion}

The results of this study reveal that there is no direct linear relationship between the number of platelets and the level of growth factors released from these platelets. Proliferation of primary osteoblast-like cells was stimulated only in a late phase by both PRP derivatives with relatively low concentrations because of dilution. Both early and late differentiations were suppressed by PRP. From the tubeformation assays, one may conclude that a relatively low concentration of activated platelets stimulates the proliferation of endothelial cells, but slightly higher concentrations have already an inhibitory effect on angiogenesis. This implies that there is an optimal concentration of plateletsstimulating target cells.

Because the platelet numbers for this optimal angiogenic effect are far beneath the physiological level in the peripheral blood of human beings, it may be that forced ex vivo activated PRP produces a different amount of growth factors, when compared with PRP or whole blood, activated under physiological conditions. It may also be that the way by which the platelets become activated ex vivo influences the biological activity of the growth factors. ${ }^{62}$ In vivo environmental factors, not present in in vitro experiments, may also play a role in the way by which the platelets become activated and in the effect of their growth factors.

Also, one has to realize that both in vivo and in vitro added PRP gets diluted. This cannot be measured in in vivo experiments, which makes it difficult to compare the results of both kinds of experiments.

The range of the optimal effective doses is probably rather small and may vary from species to species and even from individual to individual of one species. This may explain a lot of the contradictive findings of both in vivo an in vitro studies. The present study only assessed a four- to fivefold platelet concentration based on an average and a maximum value of platelets. The effect, however, of a four- to fivefold individual baseline concentration also needs to be further assessed. Till present, therefore, it is impossible to provide strict recommendations for the optimal PRP concentration. Future studies should, however, always utilize PRP with a fixed range of platelet concentrations.

\section{Disclosure Statement}

No competing financial interests exist.

\section{References}

1. Kanno, T., Takahashi, T., Tsujisawa, T., Ariyoshi, W., and Nishihara, T. Platelet-rich plasma enhances human osteoblast-like cell proliferation and differentiation. I Oral Maxillofac Surg 63, 362, 2005.

2. Marx, R.E., and Garg, A.K. Dental and Craniofacial Applications of Platelet-Rich Plasma. Chicago, IL: Quintessence Publishing Co, Inc., 2005.

3. Pierce, G.F., Mustoe, T.A., Lingelbach, J., Masakowski, V.R., Griffin, G.L., Senior, R.M., et al. Platelet-derived growth factor and transforming growth factor-beta enhance tissue repair activities by unique mechanisms. J Cell Biol 109, 429, 1989.

4. Marx, E., Carlson, E.R., Echstaedt, R.M., Schimmele, S.R., Strauss, J.E., and Georgeff, K.R. Platelet-rich plasma: growth factor enhancement for bone grafts. Oral Surg Med Oral Pathol Oral Radiol Endod 85, 638, 1998.

5. Merkx, M.A.W., Fennis, J.P.M., Verhagen, C.M., and Stoelinga, P.J.W. Reconstruction of the mandible using preshaped $2.3 \mathrm{~mm}$ titanium plates, autogenous particulate cortico-cancellous bone grafts and platelet rich plasma: a report on eight patients. Int J Oral Maxillofac Surg 33, 733, 2004.

6. Simon, E.N.M., Merkx, M.A.W., Shubi, F.M., Kalyanyama, B.M., and Stoelinga, P.J.W. Reconstruction of the mandible after ablative surgery for the treatment of aggressive, benign odontogenic tumours in Tanzania: a preliminary study. Int J Oral Maxillofac Surg 35, 421, 2006.

7. Thorn, J.J., Weis-Fogh, S.U., and Andersen, M. Autologous fibrin glue with growth factors in reconstructive maxillofacial surgery. Int J Oral Maxillofac Surg 33, 95, 2004.

8. Aghaloo, T.L., Moy, P.K., and Freymiller, E.G. Investigation of platelet-rich plasma in rabbit cranial defects: a pilot study. J Oral Maxillofac Surg 60, 1176, 2002.

9. Choi, B.H., Im, C.J., Huh, J.Y., Suh, J.J., and Lee, S.H. Effect of platelet-rich plasma on bone regeneration in autogenous bone graft. Int J Oral Maxillofac Surg 33, 56, 2004.

10. Fennis, J.P.M., Stoelinga, P.J.W., and Jansen, J.A. Mandibular reconstruction: a histological and histomorphometric study on the use of autogenous scaffolds, particulate corticocancellous bone grafts and platelet-rich plasma in goats. Int J Oral Maxillofac Surg 33, 48, 2004.

11. Kim, S.G., Chung, C., and Kim, Y. Use of particulate dentinplaster of paris combination with/without platelet-rich plasma in the treatment of bone defects around implants. Int J Oral Maxillofac Implants 17, 86, 2002.

12. Mooren, R.E.C.M., Merkx, M.A.W., Bronkhorst, E.M., Jansen, J.A., and Stoelinga, P.J.W. The effect of platelet-rich plasma on early and late bone healing: an experimental study in goats. In J Oral Maxillofac Surg 36, 626, 2007. 
13. Plachokova, A.S., Van den Dolder, J., Stoelinga, P.J., and Jansen, J.A. Early effect of platelet-rich plasma on bone healing in combination with an osteoconductive material in rat cranial defects. Clin Oral Implants Res 18, 244, 2007.

14. Schlegel, K.A., Kloss, F.R., Kessler, P., Schultze-Mosgau, S., Nkenke, E., and Wiltfang, J. Bone conditioning to enhance implant osseointegration: an experimental study in pigs. Int J Oral Maxillofac Implants 18, 505, 2003.

15. Schlegel, K.A., Donath, K., Rupprecht, S., Falk, S., Zimmermann, R., Felszeghy, E., et al. De novo bone formation using bovine collagen and platelet-rich plasma. Biomaterials 25, 5387, 2004.

16. Wiltfang, J., Kloss, F.R., Kessler, P., Nkenke, E., SchultzeMosgau, S., Zimmermann, R., et al. Effects of platelet-rich plasma on bone healing in combination with autogenous bone and bone substitutes in critical-size defects: an animal experiment. Clin Oral Implants Res 15, 187, 2004.

17. Zechner, W., Tangl, S., Tepper, G., Fürst, G., Bernhart, T., Haas, R., et al. Influence of platelet-rich plasma on osseous healing of dental implants: a histologic and histomorphometric study in minipigs. Int J Oral Maxillofac Implants 18, 15, 2003.

18. Akeda, K., An, H.S., Pichika, R., Attawia, M., Thonar, E.J.M.A., Lenz, M.E., et al. Platelet-rich plasma (PRP) stimulates the extracellular matrix metabolism of porcine nucleus pulposus and annulus fibrosus cells cultured in alginate beads. Spine 31, 959, 2006.

19. Anitua, E., Andia, I., Sanchez, M., Azofra, J., Del Mar Zalduendo, M., De la Fuente, M., et al. Autologous preparations rich in growth factors promote proliferation and induce VEGF and HGF production by human tendon cells in culture. J Orthop Res 23, 281, 2005.

20. Annunziata, M., Oliva, A., Buonaiuto, C., Di Feo, A., Di Pasquale, R., Passaro, I., et al. In vitro cell-type specifica biological response of human periodontally related cells to platelet-rich plasma. J Periodontal Res 40, 489, 2005.

21. Arpornmaeklong, P., Kochel, M., Depprich, R., Kübler, N.R., and Würzler, K.K. Influence of platelet-rich plasma (PRP) on osteogenic differentiation of rat bone marrow stromal cells. An in vitro study. Int J Oral Maxillofac Surg 33, 60, 2004.

22. Celotti, F., Colciago, A., Negri-Cesi, P., Pravettoni, A., Zaninetti, R., and Sacchi, M.C. Effect of platelet-rich plasma on migration and proliferation of SaOS-2 osteoblasts: role of platelet-derived growth factor and transforming growth factor- $\beta$. Wound Rep Reg 14, 195, 2006.

23. Choi, B.H., Zhu, S.J., Kim, B.Y., Huh, J.Y., Lee, S.H., and Jung, J.H. Effect of platelet-rich plasma (PRP) concentration on the viability and proliferation of alveolar bone cells: an in vitro study. Int J Maxillofac Surg 34, 420, 2005.

24. Doucet, C., Ernou, I., Zhang, Y., Llence, J., Begot, L., Holy, $X$. , et al. Platelet lysates promote mesenchymal stem cell expansion: a safety substitute for animal serum in cell-based therapy applications. J Cell Physiol 205, 228, 2005.

25. Ferreira, C.F., Gomes, M.C.C., Filho, J.S., Granjeiro, J.M., Simões, C.M.O., and Magini, R.S. Platelet-rich plasma influence on human osteoblasts growth. Clin Oral Implants Res 16, 456, 2005.

26. Graziani, F., Ivanovski, S., Cei, S., Ducci, F., Tonetti, M., and Gabriele, M. The in vitro effect of different PRP concentrations on osteoblasts and fibroblasts. Clin Oral Implants Res 17, 212, 2006.

27. Han, J., Meng, H.X., Tang, J.M., Li, S.L., Tang, Y., and Chen, Z.B. The effect of different platelet-rich plasma concentra- tions on proliferation and differentiation of human periodontal ligament cells in vitro. Cell Prolif 40, 241, 2007.

28. Hsu, C.-W., Yuan, K., and Tseng, C.-C. The negative effect of platelet-rich plasma on the growth of human cells is associated with secreted thrombospondin-1. Oral Surg Oral Med Oral Pathol Oral Radiol Endod 107, 185, 2009.

29. Ishida, K., Kuroda, R., Miwa, M., Tabata, Y., Hokugo, A., Kawamoto, T., et al. The regenerative effects of platelet-rich plasma on meniscal cells in vitro and its in vivo application with biodegradable gelatin hydrogel. Tissue Eng 13, 1103, 2007.

30. Kawase, T., Okuda, K., Saito, Y., Amizuka, N., Suzuki, H., and Yoshie, H. Platelet-rich plasma provides nucleus for mineralization in cultures of partially differentiated periodontal ligament cells. In Vitro Cell Dev Biol Anim 41, 171, 2005.

31. Kawase, T., Okuda, K., Saito, Y., and Yoshie, H. In vitro evidence that the biological effects of platelet-rich plasma on periodontal ligament cells is not mediated solely by constituent transforming-growth factor- $\beta$ or platelet-derived growth factor. J Periodontol 76, 760, 2005.

32. Kilian, O., Flesch, I., Wenisch, S., Taborski, B., Jork, A., Schnettler, R., et al. Effects of platelet growth factors on human mesenchymal stem cells and human endothelial cells in vitro. Eur J Med Res 9, 337, 2004.

33. Liu, Y., Kalén, A., Risto, O., and Wahlström, O. Fibroblast proliferation due to exposure to a platelet concentrate in vitro is $\mathrm{pH}$ dependent. Wound Rep Reg 10, 336, 2002.

34. Liu, Y., Zhou, Y., Feng, H., Ma, G., and Ni, Y. Injectable tissue-engineered bone composed of human adipose-derived stromal cells and platelet-rich plasma. Biomaterials $\mathbf{2 9}$, 3338, 2008.

35. Lucarelli, E., Beccheroni, A., Donati, D., Sangiorgi, L., Cenacchi, A., Del Vento, A.M., et al. Platelet-derived growth factors enhance proliferation of human stromal stem cells. Biomaterials 24, 3095, 2003.

36. Ogino, Y., Ayukawa, Y., Tsukiyama, Y., and Koyano, K. The effect of platelet-rich plasma on the cellular response of rat bone marrow cells in vitro. Oral Surg Oral Med Oral Pathol Oral Radiol Endod 100, 302, 2005.

37. Ogino, Y., Ayukawa, Y., Kukita, T., and Koyano, K. The contribution of platelet-derived growth factor, transforming growth factor- $\beta 1$, and insulin-like growth factor-I in plateletrich plasma to the proliferation of osteoblast-like cells. Oral Surg Oral Med Oral Pathol Oral Radiol Endod 101, 724, 2006.

38. Ogino, Y., Ayakawa, Y., Kukita, T., Atsuta, I., and Koyano, K. Platelet-rich plasma suppresses osteoclastogenesis by promoting the secretion of osteoprotegerin. I Periodontal Res 44, 217, 2009.

39. Okuda, K., Kawase, T., Momose, M., Murata, M., Saito, Y., Suzuki, H., et al. Platelet-rich plasma contains high levels of platelet-derived growth factor and transforming growth factor- $\beta$ and modulates the proliferation of periodontally related cells in vitro. J Periodontol 74, 849, 2003.

40. Oliva, A., Passaro, I., Di Pasquele, R., Di Feo, A., Criscuolo, M., Zappia, V., et al. Ex vivo expansion of bone marrow stromal cells by platelet-rich plasma: a promising strategy in maxillo-facial surgery. Int J Immunopathol Pharmacol 19, 45, 2006.

41. Pietramaggiori, G., Scherer, S.S., Mathews, J.C., Alperovich, M., Yang, H.-J., Neuwalder, J., et al. Healing modulation induced by freeze-dried platelet-rich plasma and micronized allogenic dermis in a diabetic wound model. Wound Rep

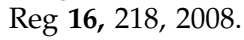


42. Roussy, Y., Bertrand Duchesne, M.-P., and Gagnon, G. Activation of human platelet-rich plasma: effect on growth factors release, cell division and in vivo bone formation. Clin Oral Implants Res 18, 639, 2007.

43. Soffer, E., Ouhayoun, J., Dosquet, C., Meunier, A., and Anagnostou, F. Effects of platelet lysates on select bone cell functions. Clin Oral Implants Res 15, 581, 2004.

44. Uggeri, J., Belletti, S., Guizzardi, S., Poli, T., Cantarelli, S., Scandroglio, R., et al. Dose-dependent effects of platelet gel releasate on activities of human osteoblasts. J Periodontol 78, 1985, 2007.

45. van den Dolder, J., Mooren, R., Vloon, A.P.G., Stoelinga, P.J.W., and Jansen, J.A. Platelet-rich plasma: quantification of growth factor levels and the effect on growth and differentiation of rat bone marrow cells. Tissue Eng 12, 3067, 2006.

46. Weibrich, G., Gnoth, S.H., Otto, M., Reichert, T.E., and Wagner, W. Wachstumsstimulation von humanen osteoblastenähnlichen Zellen durch Thrombozytenkonzentrate in vitro. Mund Kiefer GesichtsChir 6, 168, 2002.

47. Zaky, S.H., Ottonello, A., Strada, P., Cancedda, R., and Mastrogiacomo, M. Platelet lysate favours in vitro expansion of human bone marrow stromal cells for bone and cartilage engineering. J Tissue Eng Regen Med 2, 472, 2008.

48. Slapnicka, J., Fassmann, A., Strasak, L., Augustin, P., and Vanek, J. Effects of activated and nonactivated platelet-rich plasma on proliferation of human osteoblasts in vitro. J Oral Maxillofac Surg 66, 297, 2008

49. Maniatopoulos, C., Sodek, J., and Melcher, A.H. Bone formation in vitro by stromal cells obtained from bone marrow of young adult rats. Cell Tissue Res 254, 317, 1998.

50. de Ruijter, J.E., ter Brugge, P.J., Dieudonné, S.C., van Vliet, S.J., Torensma, R., and Jansen, J.A. Analysis of integrin expression in U2OS cells cultured on various calcium phosphate ceramic substrates. Tissue Eng 7, 279, 2001.

51. van den Dolder, J., Bancroft, G.N., Sikavitsas, V.I., Spauwen, P.H., Jansen, J.A., and Mikos, A.G. Flow perfusion culture of marrow stromal osteoblasts in titanium fiber mesh. $\underline{\text { Biomed }}$ Mater Res A 64, 235, 2003.

52. Tomoyasu, A., Higashio, K., Kanomata, K., Goto, M., Kodaira, K., Serizawa, H., et al. Platelet-rich plasma stimulates osteoblastic differentiation in the presence of BMPs. J Biochem Biophys Res Commun 361, 62, 2007.

53. Lu, H.H., Vo, J.M., Chin, H.S., Lin, J., Cozin, M., Tsay, R., et al. Controlled delivery of platelet-rich plasma-derived growth factors for bone formation. $\underline{\text { Biomed Mater Res A 86, }}$ $1128,2008$.
54. Cenni, E., Perut, F., Ciapetti, G., Savarino, L., Dallari, D., Cenacchi, A., et al. In vitro evaluation of freeze-dried bone allografts combined with platelet rich plasma and human bone marrow stromal cells for tissue engineering. J Mater Sci Mater Med 20, 45, 2009.

55. Krašna, K., Domanović, D., Tomšič, A., Švajger, U., and Jeras, M. Platelet gel stimulates proliferation of human dermal fibroblasts in vitro. Acta Dermatovenerol APA 3, 16, 2007.

56. Marx, R.E. Platelet-rich plasma: evidence to support its use. I Oral Maxillofac Surg 62, 489, 2004.

57. Han, B., Woodell-May, J., Ponticiello, M., Yang, Z., and Nimni, M. The effect of thrombin activation of platelet-rich plasma on demineralized bone matrix osteoinductivity. I Bone Joint Surg Am 91, 1459, 2009.

58. Huang, Q., Wang, Y.D., Wu, T., Jiang, S., Hu, Y.L., and Pei, G.X. Preliminary separation of the growth factors in plateletrich plasma: effects on the proliferation of human marrowderived mesenchymal stem cells. Chin Med J (Engl) 122, 83, 2009.

59. BD BioCoat ${ }^{\mathrm{TM}}$. Angiogenesis System-Endothelial Cell Tube Formation: Product Specification Sheet. Bedford: BD Biosciences Discovery Labware, 2006.

60. Fréchette, J.P., Martineau, I., and Gagnon, G. Platelet-rich plasmas: growth factor content and roles in wound healing. Dent Res 84, 434, 2005.

61. Hofmann, A., Ritz, U., Verrier, S., Eglin, D., Alini, M., Fuchs, S., et al. The effect of human osteoblasts on proliferation and neo-vessel formation of human umbilicial vein endothelial cells in a long-term 3D co-culture on polyurethane scaffolds. Biomaterials 29, 4217, 2008.

62. Intini, G. The use of platelet-rich plasma in bone reconstruction therapy. Biomaterials 30, 4956, 2009.

Address correspondence to: Robert E.C.M. Mooren, M.D., D.M.D. Hobbemalaan 3 $6881 \mathrm{CT}$ Velp The Netherlands

E-mail: r.mooren@chello.nl

Received: December 25, 2009 Accepted: May 24, 2010

Online Publication Date: July 1, 2010 


\section{This article has been cited by:}

1. Roberto Farina, Eriberto Bressan, Andrei Taut, Alessandro Cucchi, Leonardo Trombelli. 2012. Plasma rich in growth factors in human extraction sockets: a radiographic and histomorphometric study on early bone deposition. Clinical Oral Implants Research n/a-n/a. [CrossRef]

2. E.N.M. Simon, M.A.W. Merkx, B.M. Kalyanyama, F.M. Shubi, P.J.W. Stoelinga. 2012. Immediate reconstruction of the mandible after resection for aggressive odontogenic tumours: a cohort study. International Journal of Oral and Maxillofacial Surgery . [CrossRef]

3. Allan Fernando Giovanini, João Ricardo Almeida Grossi, Carla Castiglia Gonzaga, João Cesar Zielak, Isabella Göhringer, Juliana de Souza Vieira, Juliane Kuczera, Marco Antonio Oliveira Filho, Tatiana Miranda Deliberador. 2012. LeukocytePlatelet-Rich Plasma (L-PRP) Induces an Abnormal Histophenotype in Craniofacial Bone Repair Associated with Changes in the Immunopositivity of the Hematopoietic Clusters of Differentiation, Osteoproteins, and TGF-\#1. Clinical Implant Dentistry and Related Research n/a-n/a. [CrossRef]

4. Matthew B. Murphy, Daniel Blashki, Rachel M. Buchanan, Iman K. Yazdi, Mauro Ferrari, Paul J. Simmons, Ennio Tasciotti. 2012. Adult and umbilical cord blood-derived platelet-rich plasma for mesenchymal stem cell proliferation, chemotaxis, and cryo-preservation. Biomaterials 33:21, 5308-5316. [CrossRef]

5. Sashwati Roy, Jason Driggs, Haytham Elgharably, Sabyasachi Biswas, Muna Findley, Savita Khanna, Urmila Gnyawali, Valerie K. Bergdall, Chandan K. Sen. 2011. Platelet-rich fibrin matrix improves wound angiogenesis via inducing endothelial cell proliferation. Wound Repair and Regeneration 19:6, 753-766. [CrossRef]

6. Matthew B. Murphy, S.M. Khaled, Dongmei Fan, Iman K. Yazdi, Michael Sprintz, Rachel M. Buchanan, Christine A. Smid, Bradley K. Weiner, Mauro Ferrari, Ennio Tasciotti. 2011. A multifunctional nanostructured platform for localized sustained release of analgesics and antibiotics. European Journal of Pain Supplements 5:2, 423-432. [CrossRef]

7. Jameel Iqbal, Samuel H. Pepkowitz, Ellen Klapper. 2011. Platelet-Rich Plasma for the Replenishment of Bone. Current Osteoporosis Reports . [CrossRef]

8. Steven P. Arnoczky, Demetris Delos, Scott A. Rodeo. 2011. What Is Platelet-Rich Plasma?. Operative Techniques in Sports Medicine 19:3, 142-148. [CrossRef] 